\title{
Use of stable isotopes and mathematical modelling to investigate human mineral metabolism
}

\author{
Jack R. Dainty \\ Institute of Food Research, Norwich NR4 7UA, UK
}

Individuals have varying needs for minerals that are dependent, amongst other things, on their lifestyle, age and genetic makeup. Knowledge of exact individual nutritional requirements should lead to better health, increased quality of life and reduced need for expensive medical care. Bioavailability, nutrient-gene interactions and whole-body metabolism all need to be investigated further if we are to progress towards the goal of defining optimal health and nutritional status. The discussion which follows will critically review the latest developments in the area of metabolism for several of the minerals that are essential for human health: $\mathrm{Ca}$, $\mathrm{Zn}, \mathrm{Cu}$ and Se. Stable-isotope tracers and mathematical modelling are some of the tools being used to facilitate the greater understanding in uptake, utilisation and excretion of these minerals. Stable isotopes, administered in physiological doses, present little or no risk to volunteers and allow metabolic studies to be carried out in vulnerable population groups such as children and pregnant women. Intrinsic labelling of foodstuffs ensures that the tracer and the native mineral will behave similarly once inside the body. Advances in computing power and software dedicated to solving nutritional problems have made it possible for investigators to use mathematical modelling in their experimental work. Mineral metabolism is ideally suited to a form of modelling known as compartmental analysis, which allows rates of mineral transfer and sizes of mineral stores to be calculated accurately without the need for invasive sampling of body tissues.

Stable isotopes: Mathematical modelling: Mineral metabolism

\footnotetext{
Abbreviations: CP, caeruloplasmin; EZP, exchangeable zinc pool; IV, intravenous; SeMet, selenomethionine.
}

Corresponding author: J. R. Dainty, fax +44 01603 507723, email jack.dainty@bbsrc.ac.uk 


\section{Introduction}

Most minerals have several naturally-occurring stable isotopes, all with a fixed abundance. In order to follow the metabolism of a mineral, it is necessary to ingest it in an altered form so that it can be distinguished from the naturally-abundant mineral. The form of the ingested mineral can be altered by enriching one of the low-abundance isotopes. This so-called 'tracer' or 'label' is injected and/or taken orally and its appearance in the plasma, urine and faeces can be monitored over several days. The concept of a tracer is important in isotope work. A true tracer is one that does not perturb the system it is investigating. Only radioisotopes can be called true tracers, since they are administered in extremely small quantities. The term 'label' is more appropriate for stable isotopes, since they are usually given in quantities equivalent to the amount received in the normal diet. The word 'tracer' is, however, still used in some stable-isotope studies with the implicit understanding that it will almost certainly perturb the system under investigation. The underlying assumption in this type of work is that the label (or tracer) behaves in the same kinetic way as the naturally-abundant mineral (sometimes called the tracee), otherwise the use of labels to mimic the behaviour of the native mineral is invalid. There must be no discrimination by the body between the two forms of the mineral. Although stable isotopes were the first tracers to be used in nutritional science (Schoenheimer \& Rittenburg, 1935), radioisotopes quickly became the standard amongst researchers after the Second World War. It wasn't until the early 1960s that the first mineral study was published using an enriched stable isotope of Fe, ${ }^{58} \mathrm{Fe}$ (Lowman \& Krivit, 1963). The first studies using $\mathrm{Ca}$ (McPherson, 1965) and Cr (Donaldson et al. 1968) followed shortly afterwards, and the late 1970s saw the first $\mathrm{Zn}$ and $\mathrm{Cu}$ stable-isotope studies performed (King et al. 1978). A combination of advances in MS and concern about exposure to ionising radiation led to a growing number of researchers switching to stable-isotope tracers. Several reviews and guides have been written subsequently (Buckley, 1988; Turnlund, 1989, 1991, 1994; Mellon \& Sandstrom, 1996). The stable isotopes used in nutrition studies are normally incorporated in food either intrinsically (Janghorbani et al. 1981b; Weaver, 1985; Fox et al. 1991) or extrinsically (Janghorbani et al. 1982; Christensen et al. 1983; Johnson \& Lykken, 1988; Weaver, 1988). An intrinsic label is one in which the stable isotope is incorporated biosynthetically into a plant or animal, whereas an extrinsic label is simply added to the food before ingestion. Nutritional researchers are often interested in knowing how much of a mineral in a food, meal or diet is utilised for normal body functions. This is known as the bioavailability of the mineral. It is not possible to measure the utilisation of minerals directly so absorption and retention are used as indirect measures instead. Stable isotopes are ideal for investigating the absorption and retention of minerals because of the ease in distinguishing the label from the native element. There are two definitions of absorption: apparent and true. Apparent absorption is the quantity of mineral that is absorbed and retained in the body within the experimental time period (usually several days) from a single test meal. True absorption is the quantity of mineral that has been absorbed from a single test meal. True absorption is, by definition, always greater than apparent absorption. Knowledge of the quantity of label given and the subsequent quantity recovered in the faeces is sufficient to calculate the apparent absorption. If the mineral is prone to large endogenous losses, a second label can be given intravenously at the same time as the oral label and both are followed in the faeces. Endogenous losses can then be accounted for and the true absorption of the mineral calculated. This is known as a dual-tracer experiment and is valid if the oral and intravenous (IV) labels behave in the same way kinetically. Dual-tracer experiments can also be used to calculate true absorption from urine and plasma samples.

Recent advances in MS have been accompanied by a massive increase in computing power and software development. This advance has allowed complicated mathematical equations to 
be solved quickly. The use of mathematical modelling in nutrition has been advanced since the 1980s in conferences and workshops (Canolty \& Cain, 1985; Hoover-Plow \& Chandra, 1988; Abumrad, 1991; Siva Subramanian \& Wastney, 1995; Coburn \& Townsend, 1996; Clifford \& Muller, 1998). The vast majority of the work published from those meetings was concerned with compartmental modelling. This type of modelling is especially suited to mineral metabolism, because the kinetics of such systems can be approximated by a small number of distinct compartments connected together to form a deterministic process. Important nutritional information can be provided in a well-designed kinetic study that uses stable-isotope labels in conjunction with compartmental modelling.

Before describing why models might be useful in nutrition, some definitions must be given to clarify the terminology. A compartment is a theoretical construct that may well combine material from several different physical spaces. It is defined as an amount of material that acts as though it is well mixed and kinetically homogeneous, and a compartmental model consists of a finite number of compartments with specified interconnections between them. The interconnections are a representation of the flux of material that is transported from one location to another. By defining a compartmental model in this way, the researcher can reduce a complex metabolic system into a small number of pathways and compartments. The outputs from such a model include the quantity of mineral stored in certain body pools, the rate and extent to which the mineral moves from one pool to another and how long it will remain in the body before being excreted. This output can inform the approach of the nutritionist about status, daily requirements and mineral retention, and only by doing modelling can this sort of information be obtained from human subjects in a non-invasive way. Although compartmental models may seem complicated to the non-mathematician, the following example may help clarify some of the main issues involved.

Consider the two-compartment model shown in Fig. 1, which shows the compartments and the pathways with the direction of transfer of material. Associated with each pathway is a rate constant which is conventionally written as $k(\mathrm{i}, \mathrm{j})$ which denotes transfer of material from compartment ' $j$ ' to compartment ' $i$ ' per unit time. The type of compartment models which are usually found in nutrition are described by constant-coefficient ordinary first-order differential equations. The basis of these equations is that the rate constants do not alter over the course of the experiment, and by applying the conservation of mass to the system under study one can solve the resultant series of equations. If we denote the mass of material in compartment 1 as $\mathrm{P}$ (for plasma) and that in compartment 2 as E (the 'rest' of the body), the system can be described as:

$$
\begin{aligned}
& \frac{d \mathrm{P}}{d \mathrm{t}}=k_{1,2} \times \mathrm{E}-\left(k_{2,1}+k_{0,1}\right) \times \mathrm{P}, \\
& \frac{d \mathrm{E}}{d \mathrm{t}}=k_{2,1} \times \mathrm{P}-k_{1,2} \times \mathrm{E} .
\end{aligned}
$$

To solve these equations, we need to sample one of the two compartments so that the variables $\left(k_{0,1}, k_{1,2}\right.$ and $k_{2,1}$ ) can be fitted to the resultant data. It is often the case that the only compartment we can sample is the plasma. This limits the number of 'other' compartments we can use in our model because we will not be able to uniquely identify the variables that make up the resultant equations. This is called a priori identifiability and is used to identify, given noise-free data, the number of compartments a model may have in order that all its variables will have a single solution. Often investigators have an in-depth knowledge of the metabolism of a particular mineral and want to include many compartments to reflect this. Any model that is not a priori identifiable must be carefully evaluated and the results from it used cautiously. The fitted 


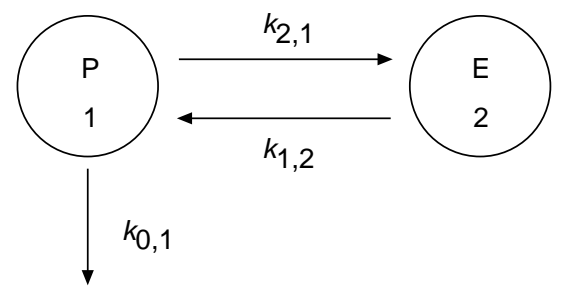

Fig. 1. Example of a two-compartment model. The two compartments are plasma $(P)$ and the 'rest' of the body $(E) . \rightarrow$, Direction of transfer of material between compartments with associated rate constant in the form $k(\mathrm{i}, \mathrm{j})$ where transfer is from $\mathrm{j}$ to $\mathrm{i}$.

variables from a model should always be quoted with their calculated precision so that an assessment of the quality of the model can be made. This is called a posteriori identifiability, and plays an important part in drawing nutritional conclusions from the modelling of real data. The a posteriori identifiability is dependent on good quality data and the correct choice of model structure for the system under investigation. Our two-compartment model is a priori identifiable. If the data from the plasma samples are of sufficient quality and they support a two-compartment rather than, say, a one- or three-compartment structure then the model should be a posteriori identifiable. A compartment model is, therefore, constrained by the type of data collected, the location it is collected from and the statistical considerations involved in fitting experimental data to models.

Closely linked with compartmental modelling is empirical modelling. This is usually applied to data generated by multiple sampling of the plasma over a few hours after an IV label has been administered. Data are plotted semilogarithmically and then fitted to an exponential equation of the form:

$$
\mathrm{y}(\mathrm{t})=\sum_{\mathrm{i}=1}^{n} A_{i} \exp \left(-a_{i} \mathrm{t}\right),
$$

where $n$ is an integer between 1 and 4 which is determined on fitting the data, $A_{i}$ and $a_{i}$ are coefficients also determined on fitting. At most, only four exponential equations can be determined from plasma sampling for reasons discussed in Landaw \& DiStefano (1984). Kinetic variables of interest such as transit time (the time an average molecule spends in plasma during a single transit), plasma residence time (the total time an average molecule spends in plasma before irreversible loss), the recycling number (the total number of times an average molecule recycles through plasma before irreversible loss), mean sojourn time (the total time an average molecule spends in the body, after introduction into the plasma, before irreversible loss) and the total traced mass in the system can all be computed from the fitted variables. The drawback to empirical models is that they tell you nothing about mineral absorption, endogenous losses or bioavailability. This type of modelling also makes the assumption that the mineral introduced into the plasma via an IV injection behaves in the same kinetic way as the mineral that appears in the plasma through the oral route. It cannot be assumed that a mineral introduced into the body by different methods will be transported in the plasma in the same way. If the transport mechanism is different then the clearance rate will also be different and the kinetic behaviour will not be the same. In modelling a nutritional system the oral route of label administration is preferred because this is how we consume minerals from food in our everyday lives. Due to 
these considerations, compartmental models are much more widely used than empirical models in mineral research, and this is reflected in the models cited in the present review.

A comprehensive literature exists on both compartmental and empirical modelling (Atkins, 1969; Shipley \& Clark, 1972; Anderson, 1983; Carson et al. 1983; Green \& Green, 1990; Wolfe, 1992; Jacquez, 1996; Wastney et al. 1999) and they are both well-grounded theoretically. Dedicated software tools such as SAAMII (1997) allow non-mathematicians to set up compartmental and empirical models without the need to define the differential equations that underpin them.

The present review focuses on the metabolism of $\mathrm{Cu}, \mathrm{Ca}, \mathrm{Zn}$ and $\mathrm{Se}$ and cites specific examples from the literature where modelling with stable isotopes has been carried out in human volunteers.

\section{Copper}

\section{Background}

$\mathrm{Cu}$ is essential for man and is involved in many enzyme systems in the body (Linder, 1991). It is a difficult element to study because it only has two stable isotopes $\left({ }^{63} \mathrm{Cu} 69 \cdot 2 \%\right.$ and ${ }^{65} \mathrm{Cu}$ $30.8 \%$ ), which means that oral and IV labels cannot be given simultaneously. Endogenous losses play a significant role in Cu metabolism (Turnlund, 1998) and are usually quantified by IV dose in conjunction with faecal monitoring (Turnlund et al. 1998). There is potential to measure endogenous losses by ingesting an oral isotope and examining appearance of label once all the unabsorbed isotope has been excreted. Extrapolation back to the time of isotope administration can allow a correction for endogenous losses in the collected stools to be made. $\mathrm{Cu}$ exists in two distinct forms in the plasma; the non-caeruloplasmin (CP) or albumin-bound fraction is the form in which the $\mathrm{Cu}$ appears in the plasma following a meal (Linder, 1998). Most of this form is rapidly converted to the $\mathrm{CP}$ form in the liver. This process creates a problem in modelling $\mathrm{Cu}$ metabolism because it is difficult to separate and measure accurately the quantity of $\mathrm{Cu}$ in the two forms (Buckley et al. 1996). The last Committee on Medical Aspects of Food Policy report on dietary reference values (Department of Health, 1991) stated that there were no adequate data on human $\mathrm{Cu}$ requirements, and they were unable to derive estimated average requirements or lower recommended nutrient intakes with sufficient confidence. Also, there is no reliable biochemical measure of $\mathrm{Cu}$ status, nor is it understood what factors affect $\mathrm{Cu}$ bioavailabilty.

\section{Studies}

In contrast to the other main minerals of nutritional interest, very few papers have been published that attempt to model $\mathrm{Cu}$ metabolism in man using stable isotopes, although work has been done using animal models (Buckley, 1991; Dunn et al. 1991). These studies were used as the basis for the human model of Scott \& Turnlund (1994a) in which five young men took part in a 90-d intervention trial. The study was divided into three metabolic periods: adequate $\mathrm{Cu}$ $(1.68 \mathrm{mg} / \mathrm{d}$ for $24 \mathrm{~d})$, low $\mathrm{Cu}(0.785 \mathrm{mg} / \mathrm{d}$ for $42 \mathrm{~d})$ and high $\mathrm{Cu}(7.53 \mathrm{mg} / \mathrm{d}$ for $24 \mathrm{~d})$, with the $\mathrm{Cu}$ (as a $\mathrm{CuSO}_{4}$ solution) added to the diet during all three metabolic periods. A solution containing $392 \mu \mathrm{g}{ }^{65} \mathrm{Cu}$ was infused on days 7, 49 and 73 of the study and an oral dose ingested on days $13(1600 \mu \mathrm{g}), 31$ or $32(1020 \mu \mathrm{g}), 55$ or $56(1020 \mu \mathrm{g})$ and $79(7660 \mu \mathrm{g})$. The model consists of five compartments, two delays and two excretion routes (Fig. 2). Only data from plasma 


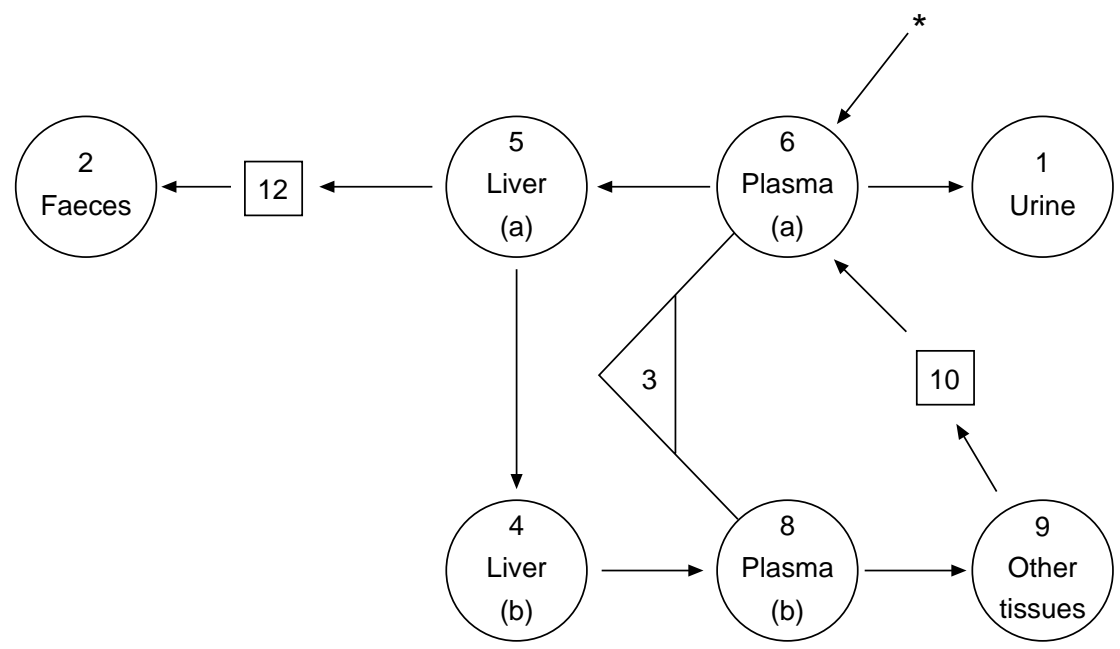

Fig. 2. Compartmental model of copper metabolism in adult men. The compartments are liver, plasma, urine, faeces and other tissues. $(\square)$, Delays; $(\triangle)$, sum of the indicated compartments; ${ }^{*}$, site of ${ }^{65} \mathrm{Cu}$ input; $\rightarrow$, direction of transfer of material between compartments. Plasma samples were taken from compartment 3. (From Scott \& Turnlund 1994a; reproduced with permission.)

samples were used to fit the rate constants in the compartment model. Although two plasma compartments were specified, no attempt was made to quantify the separate $\mathrm{Cu}$-containing plasma fractions. According to the investigators, no single set of variables could be found to fit all the data, so the oral and IV data were fitted separately for each metabolic period. No theory was given as to why the different routes of tracer administration might lead to dissimilar kinetics. The model predicted that the half-life of $\mathrm{Cu}$ in the compartment identified with the non-CP form was approximately $40 \mathrm{~min}$. This value is higher than that found in the only other two studies that have attempted to measure the half-life of non-CP-bound Cu. Buckley et al. (1996) reported lower half-lives $(8.7$ and $12.3 \mathrm{~min})$ in two volunteers after IV infusion with a ${ }^{65} \mathrm{Cu}$ label. These values agreed with those of D'Addabbo et al. (1971) of 8.5 and $10 \mathrm{~min}$ for the half-life of ${ }^{64} \mathrm{Cu}$ in two subjects after IV injection.

Although Scott \& Turnlund (1994a) did not include urinary data in their model, this should not influence the accuracy since it is well known (Turnlund et al. 1990) that urinary excretion makes up a very small percentage of the total endogenous excretion and is relatively constant. The lack of any faecal data is a drawback. It is thought that as much as $4.5 \mathrm{mg} / \mathrm{d}$ of endogenous $\mathrm{Cu}$ may be secreted into the gastrointestinal tract (Linder, 1998). Since the average dietary intake is approximately $1 \mathrm{mg} / \mathrm{d}$, it is evident that most of the secreted $\mathrm{Cu}$ is reabsorbed to maintain zero balance. Turnlund et al. (1998) found that about $20 \%$ of the absorbed $\mathrm{Cu}$ from a meal is eventually lost in the faeces. Any model of $\mathrm{Cu}$ metabolism should include this excretion pathway if it is to be physiologically relevant. The Scott \& Turnlund (1994a) model incorporates a biliary excretion path that predicts that about $0.15 \mathrm{mg} / \mathrm{d}$ will be excreted with moderate $\mathrm{Cu}$ intake $(1.68$ $\mathrm{mg} / \mathrm{d}$ ) and Turnlund et al. (1998) found a similar experimental value. However, a re-absorption pathway should be included in any future model to account for known physiology.

Despite the limitations of their model, the findings from Scott \& Turnlund (1994a) generated important information. The total body $\mathrm{Cu}$ content was predicted to be between 75 and 98 mg compared with 49-118 mg reported in previous literature (Davis \& Mertz, 1987; Linder, 1991). The model also predicted that $4.5 \%$ of the total body $\mathrm{Cu}$ was in the plasma compared with literature estimates of 2-6\%. Of the plasma $\mathrm{Cu}, 62-72 \%$ was estimated to be $\mathrm{CP}-$ bound. 
This estimate is comparable with research by Wirth \& Linder (1985), who found that approximately $60 \%$ was CP-bound, whilst Owen (1982) estimated that $90 \%$ of plasma $\mathrm{Cu}$ was bound to $\mathrm{CP}$. The route of administration was found to influence some of the rate constants. This finding is a clear indication that the body handles oral and IV $\mathrm{Cu}$ differently and calls into question the use of IV tracers to quantify re-excretion of dietary $\mathrm{Cu}$.

The only other stable-isotope paper that contains a compartmental model of human $\mathrm{Cu}$ metabolism is that by Buckley (1996). This model contains ten compartments and sixteen rate constants. The variables are derived from literature values and known human physiology of $\mathrm{Cu}$. The model is used to simulate how different dietary levels of $\mathrm{Cu}$ might influence endogenous excretion and, ultimately, $\mathrm{Cu}$ levels in the liver, muscle and other tissues. The paper points out a very useful and largely overlooked use of compartmental modelling in predicting what might theoretically happen during an experiment. This information can be used to optimise the design of the subsequent study in areas such as sampling times, dose size and required precision of MS measurements.

\section{Future work}

Future work on designing models of $\mathrm{Cu}$ metabolism should include the collection of faecal samples, a longer period of blood sampling and the separation of $\mathrm{CP}$ - and non-CP-bound $\mathrm{Cu}$ fractions in the plasma. An extended period of blood sampling will allow the appearance of labelled CP to be fully quantified. Also, the re-absorption pathway from the gut should be included; it must be present as the body reuses most of the very large amount of $\mathrm{Cu}$ excreted in bile and pancreatic juices.

Care must also be exercised in the choice of route for label administration. Two possible reasons why IV $\mathrm{Cu}$ may be metabolised differently are: (1) the chemical form administered; (2) the rate of administration. Both these factors could cause the IV $\mathrm{Cu}$ to be bound and transported differently in the plasma from $\mathrm{Cu}$ in a meal. If it is demonstrated that IV and oral $\mathrm{Cu}$ behave differently, the use of IV dosing must be restricted to studies where information on parenteral feeding is required.

Studies on mineral bioavailability should be carried out using intrinsically-labelled foods in conjunction with a controlled $\mathrm{Cu}$ diet. This procedure has a dual purpose: first, that a physiological dose in the correct chemical form is consumed; second, the volunteers will be in a steady-state and any resultant model will relate directly to the quantity of $\mathrm{Cu}$ they have received over several days. In other words, transient confounding effects will be minimised.

At present, dietary intervention studies are used to investigate mineral bioavailability. Used in conjunction with a compartmental model, intervention studies could yield much more information about the homeostatic control points in the body. It should be possible to see which body stores of $\mathrm{Cu}$ are mobilised during a shortage of dietary $\mathrm{Cu}$ and, conversely, where $\mathrm{Cu}$ is stored and at what rate in times of plenty. Knowledge of this sort will enable more appropriate dietary recommendations to be made.

\section{Zinc}

\section{Background}

$\mathrm{Zn}$ is the second most abundant trace element in man and is essential for the transmission of the genetic message, cell division, cell differentiation and growth. There are more than 300 
enzymes containing $\mathrm{Zn}$ and it is essential for the maintenance of membrane stability. The use of stable isotopes in the study of $\mathrm{Zn}$ metabolism in human subjects began in the early 1980s (Jackson et al. 1984). Several reviews (Krebs et al. 1995; Wastney et al. 2000) deal specifically with $\mathrm{Zn}$ metabolism, whilst others focus on status (King, 1990). The driving force behind the use of modelling in $\mathrm{Zn}$ research is mainly due to the lack of a good biochemical status indicator. $\mathrm{Zn}$ status has been estimated from the plasma $\mathrm{Zn}$ concentration, but this value is known to vary markedly due to stress, infection and glucocorticoids (Cousins, 1989). Although erythrocyte metallothionein has been suggested as a useful status marker (Grider et al. 1990, Sullivan et al. 1998), more studies are needed to evaluate its usefulness. Zn requirements have traditionally been estimated from the difference between $\mathrm{Zn}$ intake and a measurement of obligatory losses. This is another area where modelling input can be helpful in identifying rates of transfer between body pools.

\section{Studies}

There have been numerous compartmental models developed using radioisotopes, two of which (Foster et al. 1979; Wastney et al. 1986) were used as the basis for the stable-isotope model of Scott \& Turnlund (1994b). They studied the effect of three different dietary levels of $\mathrm{Cu}$ on $\mathrm{Zn}$ metabolism in five adult men. Fig. 3 shows a schematic representation of their model. Two liver compartments, two erythrocyte compartments and five other tissue compartments were used to fit the data. It is highly unlikely that such a detailed model could be developed using stable-isotope data. The experiment was conducted over $90 \mathrm{~d}$ and divided into three metabolic periods

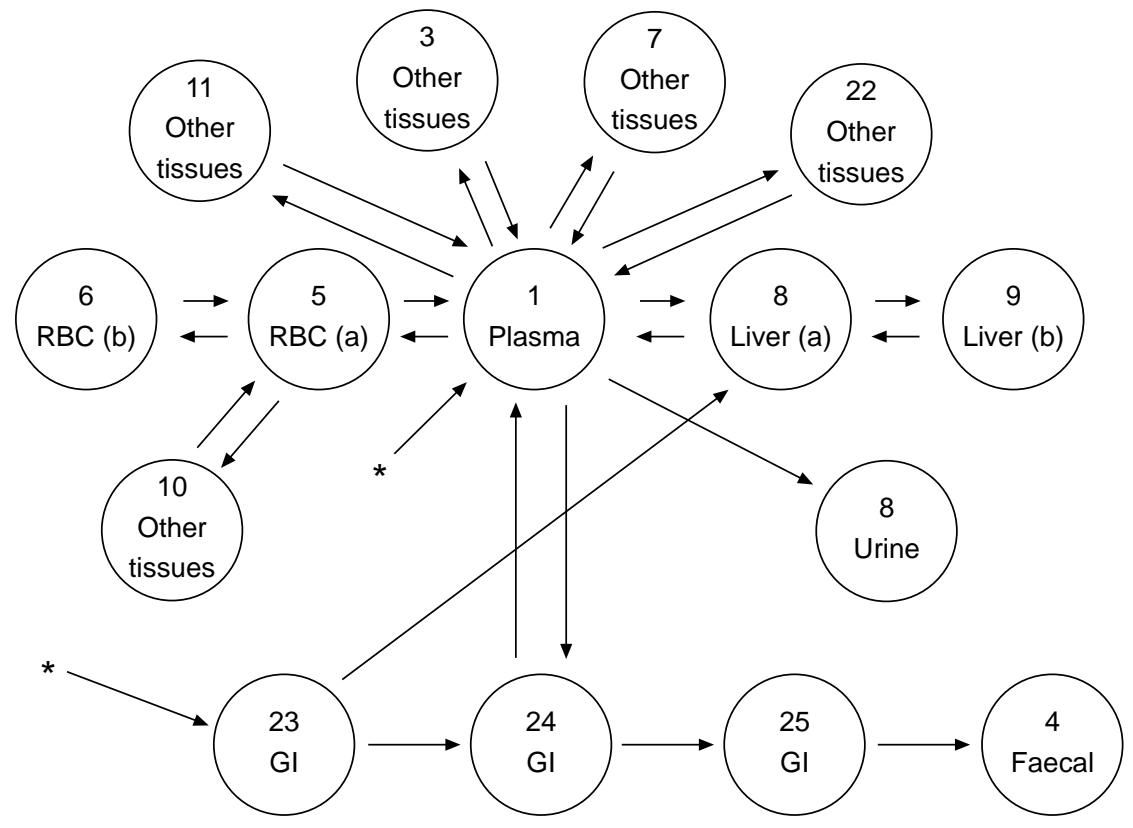

Fig. 3. Compartmental model of zinc metabolism in adult men analysed using the CONSAM program (Foster et al. 1989). The compartments are plasma, erythrocytes (RBC), liver, other tissues, gastrointestinal tract (Gl) and faeces. *, Sites of isotope input; $\rightarrow$, direction of transfer between compartments, a rate constant of the form $\mathrm{L}_{(\mathrm{i}, \mathrm{j})}$ (transfer from $\mathrm{j}$ to $\mathrm{i}$ ) being associated with each transfer (not shown). (From Scott \& Turnlund, 1994b; reproduced with permission.) 
consisting, nominally, of medium, low and high $\mathrm{Cu}$ intakes. $\mathrm{Zn}$ intake was kept constant at approximately $11 \mathrm{mg} / \mathrm{d}$ over the study period. Oral ${ }^{67} \mathrm{Zn}$ was given on days 13, 31, 55 and 79 . IV ${ }^{70} \mathrm{Zn}$ was given on days 7, 49 and 73 . Blood, urine and faecal samples were collected on the study days and for several days thereafter. On fitting the data it was found that excretion into the gastrointestinal tract (rate constant $\mathrm{L}(24,1)$ ) depended on route of administration and was lower after the IV dose than the oral dose. All other rate constants, however, showed no effect of route of administration. The main finding from the study was that only three of the rate constants were affected by the different levels of $\mathrm{Cu}$ in the metabolic periods. These were: $\mathrm{L}(1,24)$; $\mathrm{L}(12,1)$; L(24,23). All other rate constants were not affected by dietary $\mathrm{Cu}$ level and their values did not differ by more than $4 \%$ from those found by Wastney et al. (1986). Compartment masses were also in agreement with those predicted by Foster et al. (1979) and Wastney et al. (1986). Total body $\mathrm{Zn}$ was calculated to be in the range $1800-2300 \mathrm{mg}$, of which $95 \%$ was found in the 'other tissues' compartments. Predictions for the total $\mathrm{Zn}$ in the liver compartments ranged from 66 to $80 \mathrm{mg}$, and that in the erythrocytes was estimated to be about $30 \mathrm{mg}$. It should be noted that half the predicted rate constants have $\mathrm{CV}$ of more that $50 \%$. Particularly uncertain (CV in excess of $1000 \%$ ) are the predicted values for the rate of return of $\mathrm{Zn}$ from the other tissue compartments (3, 7 and 22) to the plasma. Since these compartments probably represent bone and skeletal muscle, an investigation of several months is needed to predict accurately the rate of return of label from these slowly-turning-over compartments. This factor indicates that a simpler model would have been more appropriate for this study. Another shortcoming, as pointed out by the authors, was that only a few blood samples were taken after administration of the oral doses. This procedure would not have allowed proper characterisation of the initial appearance of the label in the plasma. It is, therefore, quite difficult to say whether the oral and IV doses are handled in the same way by the body. In a separate study Wastney et al. (1991) used the same model structure as shown in Fig. 3 and found that a ${ }^{70} \mathrm{Zn}$ oral dose of $1.99 \mathrm{mg}$ gave very similar kinetic results to an oral dose of ${ }^{65} \mathrm{Zn}$ (a radioisotope) given at the same time. This finding is important, since one of the criticisms of stable-isotope research is that the dose sizes are too large and therefore they do not act as true tracers.

A subsequent stable-isotope study by Lowe et al. (1997) used a much simpler model (Fig. 4). Only six compartments are estimated from the stable-isotope labels, although a seventh is included (compartment 7) because it was calculated by another method. Six healthy women were recruited and placed on a constant $\mathrm{Zn}$ diet $(7 \mathrm{mg} / \mathrm{d})$ for $7 \mathrm{~d}$ before the study day and $7 \mathrm{~d}$ subsequent to it. Label administration was a simultaneous oral $\left({ }^{67} \mathrm{Zn}\right)$ and IV $\left({ }^{70} \mathrm{Zn}\right)$ dose followed by blood, urine and faecal sampling for up to $11 \mathrm{~d}$ afterwards. The model was developed on the basis of known physiology and the minimum number of compartments required to adequately fit the data. The resulting model was a priori identifiable according to the GLOBI program (Saccomani et al. 1994). This means that all the variables had a single possible solution. It was also a posteriori identifiable, meaning that all variables were estimated with good precision from the experimental data. Compartments 2, 3 and 7 have not been named explicitly, but the authors speculate that compartments 2 and 3 are some combination of liver, erythrocytes and kidney. The mass of compartment 7 was estimated by assuming it contained $\mathrm{Zn}$ stored in the rest of the body (skeletal muscle and bone). This value could not be calculated from the stable isotope data because the label was not returned from it within the $7 \mathrm{~d}$ study period. Previous radioisotope studies (Foster et al. 1979; Wastney et al. 1986) have estimated skeletal muscle and bone to contain approximately $95 \%$ of the body Zn. Griffin et al. (2000) compared results from this model with those from the same model but with an added erythrocyte compartment that exchanges with the plasma compartment. Body-weight-corrected $\mathrm{Zn}$ pool masses were found to be significantly greater $(P<0 \cdot 05)$ in children than in adults. 


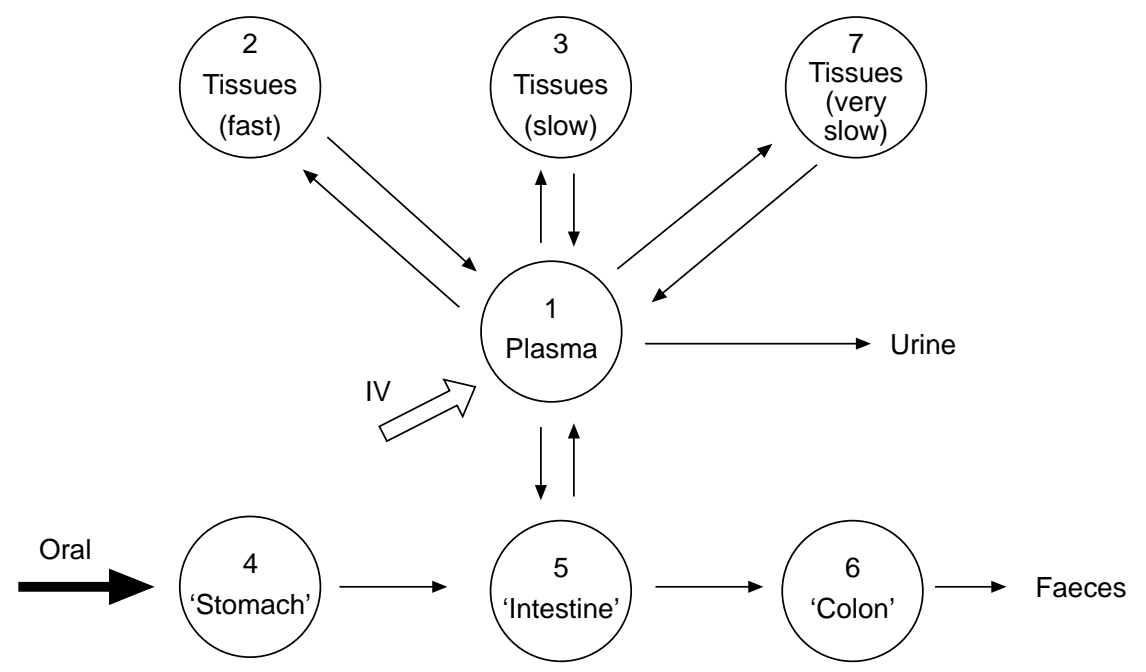

Fig. 4. 'Tracer' compartmental model. Although compartment 7 (Tissues (very slow)) is indicated, the rate constant $L(1,7)$ and compartment mass $\left(M_{7}\right)$ could not be resolved from the data and were estimated by other means (see p. 303). $\rightarrow$, Direction of transfer between compartments; IV, intravenous. (From Lowe et al. 1997; reproduced with permission.)

The most recent multi-compartmental model is that developed by Miller et al. (1998) using two oral labels $\left({ }^{67} \mathrm{Zn},{ }^{68} \mathrm{Zn}\right)$ and one IV $\left({ }^{70} \mathrm{Zn}\right)$ label. Blood, urine and faeces were collected and a constant daily diet was adhered to over the course of the experiment. As shown in Fig. 5, fourteen compartments were identified as contributing to $\mathrm{Zn}$ metabolism over the $9 \mathrm{~d}$ study period. This structure was not shown to be a priori identifiable, but was shown to be $a$ posterori identifiable. As well as the tracer data, use was made of information from the published literature on tracee excretion, absorption, circulation and storage. A large part of the paper is taken up with an in-depth explanation of the rationale behind the model. One volunteer's data are thoroughly examined and the stages through which the experimenter must go in order to fit a model to the data are examined in detail. The compartments that are included as part of the rapidly-exchanging $\mathrm{Zn}$ pool (EZP) are indicated in Fig. 5. The criterion for inclusion was defined as any compartment with IV label enrichment equal to that in the plasma $( \pm 25 \%)$ by 72 hours after label administration. This readily exchangeable zinc accounts for only about $5 \%$ of the total body $\mathrm{Zn}$ but is thought to be involved in the known physiological functions of the element. An estimate of the EZP for subject 1, based on the compartmental model, was $141 \mathrm{mg}$. An alternative method (Miller et al. 1994), which uses a measure of the plasma or urine enrichment, calculated the EZP to be $180 \mathrm{mg}$, an overestimation of about $28 \%$.

The EZP can, as mentioned earlier, be calculated without the need for a full compartmental model. This was first shown by Miller et al. (1994) who demonstrated that plasma or urine enrichment data could be used to estimate the EZP. By assuming that the pools that make up the EZP can be combined (after $48 \mathrm{~h}$ ) into one 'EZP compartment', a single exponential function can be fitted to either plasma or urine enrichment data collected $2 \mathrm{~d}$ after IV or oral administration. An additional requirement with oral enrichment data is that the absorption of the dose must be known. Enrichment in this case is defined as:

$\mathrm{EZP}$ enrichment $=$ mass of isotope label in EZP/total EZP mass. 


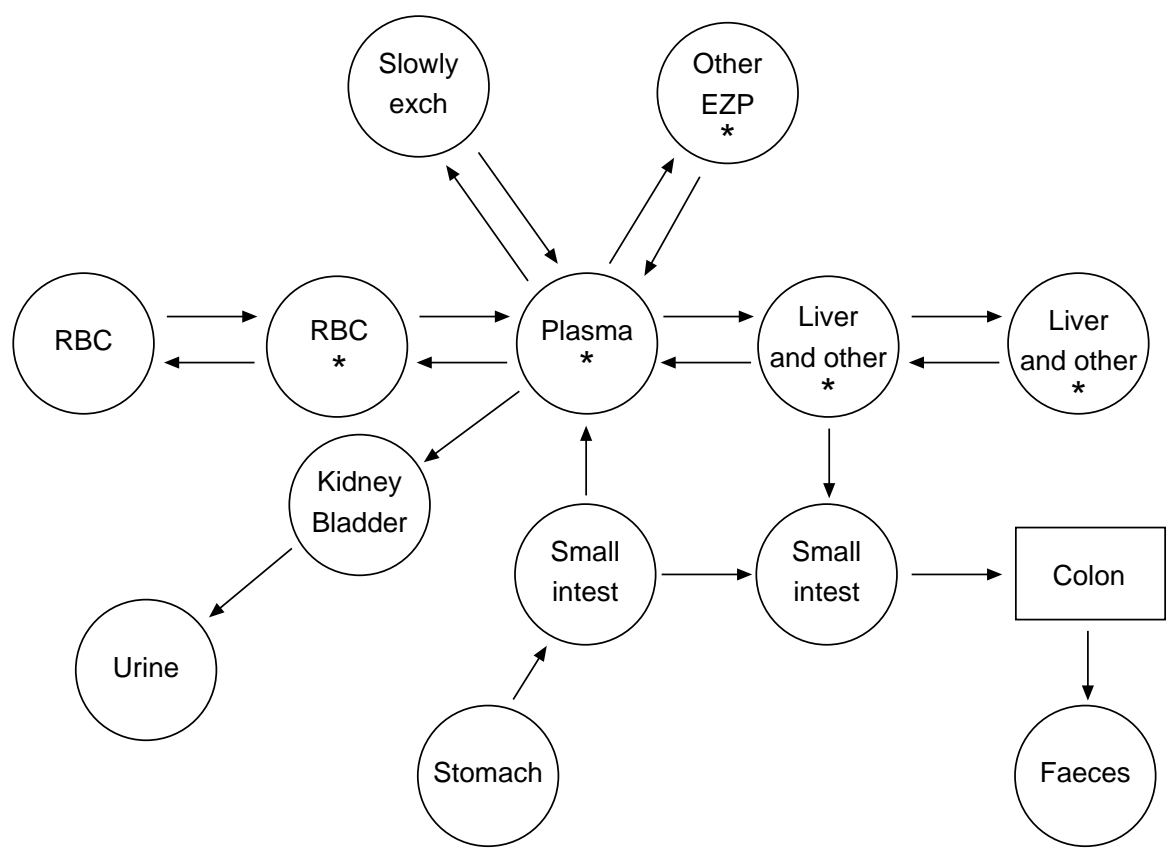

Fig. 5. Compartmental model of zinc metabolism. The colon represents a delay element. *, Compartments included in the exchangeable $\mathrm{Zn}$ pool (EZP); $\rightarrow$, direction of transfer between compartments; RBC, erythrocytes; exch, exchanging; intest, intestine. (From Miller et al. 1998; reproduced with permission.)

By plotting the natural logarithm $\left(\log _{\mathrm{e}}\right)$ of the EZP enrichment $v$. time (for data collected $2 \mathrm{~d}$ after oral dosing), a straight line is produced which is an indication that labelled $\mathrm{Zn}$ is being cleared out of a single compartment (the EZP). By extrapolating the straight line back to the time of label administration, the size (mass) of the EZP can be calculated. Several assumptions are made in this type of modelling: (1) the loss of isotopic label from the EZP occurs at a mono-exponential rate from the time of label administration; (2) the label is homogeneously mixed with the EZP during the measurement period. These two assumptions lead to an inherent overestimation of EZP. Miller et al. (1994) found this overestimation to be about $24 \%$ when they fitted their data to a compartmental model (Wastney et al. 1986). The subsequent paper (Miller et al. 1998) found an overestimation of about $28 \%$. If this error is consistent then it is not an impediment to the use of this type of calculation for predicting the EZP size. The method has been used by several investigators (Sian et al. 1996; Watson et al. 1999). Other workers have also calculated EZP size using compartmental modelling (Fairweather-Tait et al. 1993; Lowe et al. 1993).

\section{Future work}

Future work would benefit from a study design incorporating a controlled diet before and during the experimental period. Studies using intrinsic labels of $\mathrm{Zn}$ should also be encouraged. There is no definitive evidence that oral and IV $\mathrm{Zn}$ are handled in the same way by the body. The effect of size of IV dose and rate of infusion should be examined in relation to the subsequent appearance in plasma, urine and faeces. There is also some evidence that the size of the 
oral dose affects the quantity that is absorbed due to competition with endogenous Zn (Sian et al. 1993). Care must be taken in study design to minimise the quantity of oral dose if it is to be given in a meal.

There have been few studies involving pregnant or lactating women. There is an increased need for $\mathrm{Zn}$ during these periods, and the results from one study led the researchers to suggest that the extra $\mathrm{Zn}$ comes from bone resorption of the mother (Moser-Veillon, 1995). Unfortunately, this study assumed that all the $\mathrm{Zn}$ in the skeleton was available for resorption. In fact, only the trabecular bone can be broken down rapidly and this accounts for just $20 \%$ of the overall skeleton. Estimates of bone resorption, using stable isotopes, are prone to large error so future pregnancy and/or lactation studies must be well planned.

\section{Calcium}

\section{Background}

$\mathrm{Ca}$ is a mineral with a long history of metabolic studies using radio- and stable-isotope tracers. This is hardly surprising given its important role in human physiology in areas such as cell signalling and bone health. Almost $99 \%$ of the $\mathrm{Ca}$ in human subjects resides in the skeleton, where bone is a dynamic part of the body and is in constant flux. Ca homeostasis must be closely regulated because of the role of $\mathrm{Ca}$ in cell signalling. Thus, when the body is in need of $\mathrm{Ca}$, bone is broken down and the Ca released into the circulation. Between the ages of 20 and 40 years, bone loss is approximately equal to bone growth, so that net bone remains constant. The situation is somewhat different for post-menopausal women. Bone is lost at an increasing rate and may therefore result in osteoporosis. Bone density measurements and bone biomarkers cannot detect subtle changes in bone dynamics that might indicate the onset of osteoporosis (Marcus et al. 1999). Bone biomarkers are subject to high variability and are not a sensitive index of changes in Ca metabolism resulting from nutritional factors. Stable-isotope tracers and mathematical modelling can provide an accurate picture of $\mathrm{Ca}$ kinetics and can give some estimation of bone turnover. The double-isotope technique is useful for $\mathrm{Ca}$ absorption studies since the oral and IV forms of Ca have been shown to follow similar kinetics once in systemic circulation. When this technique is used in conjunction with balance studies, a wide range of $\mathrm{Ca}$ kinetics and body pool sizes can be determined. Precise blood sampling and complete urine and faecal collections need to be made and samples analysed for the Ca from the naturally-abundant source (both endogenous and dietary) and the oral and IV labels.

\section{Studies}

A recent paper by Wastney et al. (1996) examined the differences in Ca kinetics between adolescent girls and young women. Healthy adolescent $(n 14)$ and adult $(n 11)$ subjects were given a controlled diet with $\mathrm{Ca}$ intakes of approximately $1300 \mathrm{mg} / \mathrm{d}$ for $7 \mathrm{~d}$ before receiving oral $\left({ }^{44} \mathrm{Ca}, 98.5 \%\right.$ enrichment $)$ and IV $\left({ }^{42} \mathrm{Ca}, 93.6 \%\right.$ enrichment $)$ doses. Blood was sampled at frequent intervals for the next few hours and then daily for $14 \mathrm{~d}$. All urine and faeces were also collected for 2 weeks. The model is shown in Fig. 6. Compartment 1 contains the vascular space and some of the extracellular fluid, compartment 2 is soft tissue and compartment 3 contains exchangeable $\mathrm{Ca}$ in bone. The rate constants between the three compartments were derived using the IV plasma data. One possible limitation of this work is that the initial volume 
of distribution in compartment 1 could not be well determined and was fixed at ten, one and five times vascular space in various volunteers. Neer et al. (1967) found that the size of the sampled compartment (compartment 1) was approximately four times the vascular space. They speculated that this factor was due to $\mathrm{Ca}$ penetration of capillary walls and/or adsorption to endothelial surfaces.

The rate of endogenous faecal excretion $\left(\mathrm{V}_{\mathrm{f}}\right)$ was calculated from the cumulative appearance of the IV dose in the faeces. The rate of urinary excretion $\left(\mathrm{V}_{\mathrm{u}}\right)$ and dietary faecal excretion $\left(\mathrm{V}_{\mathrm{F}}\right)$ were both calculated from the appearance of naturally-abundant $\mathrm{Ca}$ in the urine and faeces respectively. Knowledge of $\mathrm{V}_{\mathrm{u}}$ and $\mathrm{V}_{\mathrm{F}}$, along with the daily intake of $\mathrm{Ca}\left(\mathrm{V}_{\mathrm{i}}\right)$ permits the calculation of Ca balance $\left(\Delta=\mathrm{V}_{\mathrm{i}}-\left(\mathrm{V}_{\mathrm{F}}+\mathrm{V}_{\mathrm{u}}\right)\right)$. The rate of bone deposition of the IV label can be estimated by fitting the IV plasma data to this model. The rate of bone deposition of the naturally-occurring $\mathrm{Ca}\left(\mathrm{V}_{0+}\right)$ can then be calculated from knowledge of the mass of $\mathrm{Ca}$ in compartment 3. The rate of bone resorption $\left(\mathrm{V}_{0-}\right)$ cannot be measured directly from stable-isotope data, since it takes several months for dietary $\mathrm{Ca}$ laid down in the bone to be returned to the plasma. Instead, $\mathrm{V}_{0-}$ must be calculated by difference $\left(\Delta=\mathrm{V}_{0+}-\mathrm{V}_{0-}\right)$. Calculations of this type indicate that, in comparison with adult women, adolescent girls resorb more $\mathrm{Ca}$ from their skeleton $(1177 v .542 \mathrm{mg} / \mathrm{d})$, deposit more $\mathrm{Ca}$ in their bone $(1459$ v. $501 \mathrm{mg} / \mathrm{d})$ and therefore retain more Ca $(282 v .-41 \mathrm{mg} / \mathrm{d})$. A loss of Ca of $41 \mathrm{mg} / \mathrm{d}$, as estimated for women, would eventually lead to detrimental structural changes in the skeleton and increase the risk of fracture in later life. It is essential that the error or uncertainty is quoted with such calculations so that other investigators can evaluate the precision of the data.

A structurally-identical model to that shown in Fig. 6 was employed by Smith et al. (1996) to calculate Ca kinetics. Based on a similar sampling protocol to that of Wastney et al. (1996), but with the addition of saliva sampling and much smaller dose sizes, the study only used two volunteers (one male, one female) and did not include a controlled diet, either before or during the study. Balance could not, therefore, be guaranteed, and all results were based on an estimated

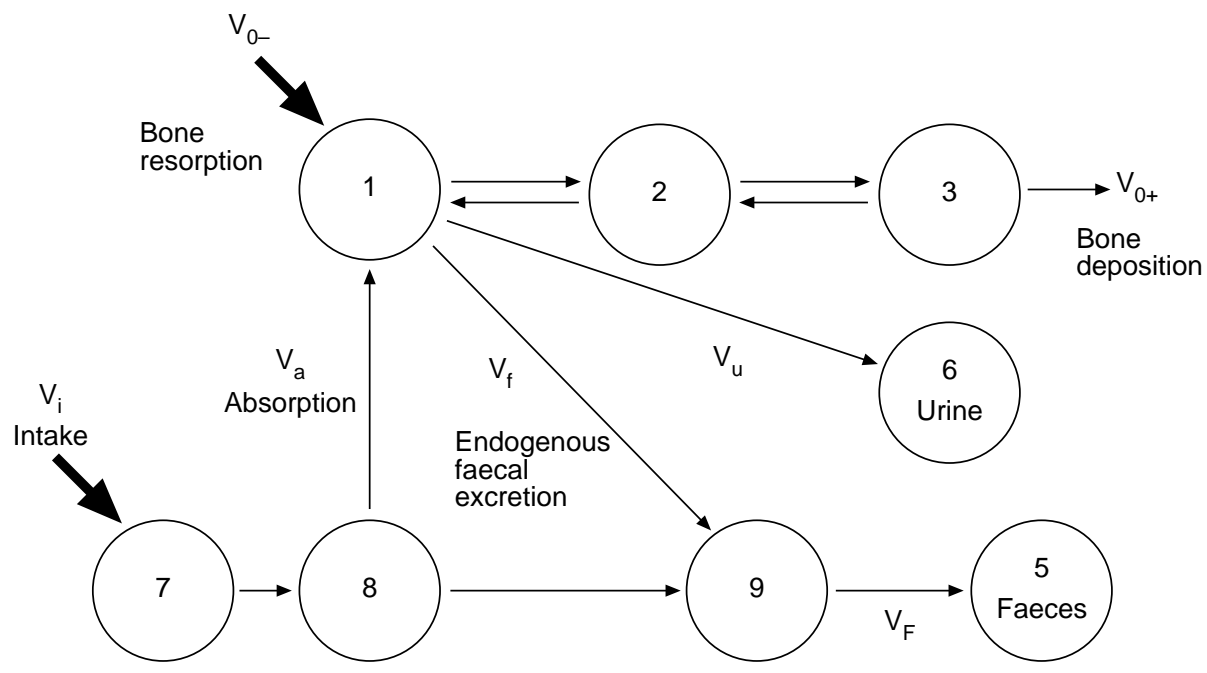

Fig. 6. Model for calcium metabolism in women. The notation of the transport rates are after that of Aubert et al. (1963). The compartments are shown together with their compartment number. $\rightarrow$, Movement between compartments; $\longrightarrow$ entry of $\mathrm{Ca}$ via the diet $\left(\mathrm{V}_{\mathrm{i}}\right)$ or bone resorption $\left(\mathrm{V}_{0_{-}}\right) ; \mathrm{V}_{\mathrm{a}}$, rate of $\mathrm{Ca}$ absorption; $\mathrm{V}_{0_{+}}$, deposition in bone; $V_{u}$, urine excretion; $V_{f}$, endogenous faecal excretion; $V_{F}$, faecal excretion. (From Wastney et al. 1996; reproduced with permission.) 
daily $\mathrm{Ca}$ intake for both volunteers. It was shown that the small doses still gave measurable enrichment using high-precision thermal ionisation MS. This led to the conclusion that saliva samples could be used alongside blood samples to calculate Ca kinetics. Again, because no error or uncertainties were quoted in the paper, the use of smaller doses cannot be properly evaluated.

Similar techniques have been used by Abrams et al. (1992, 1994). The later study (Abrams, 1994) found a very high bone Ca deposition rate (160 mg/kg per d) amongst thirteen very-lowbirth-weight infants fed a high-Ca diet. The earlier paper (Abrams, 1992) used an empirical model of Ca kinetics, in conjunction with urine and plasma data, to derive an equation containing three exponential terms.

The total exchangeable pool size and the rate of bone absorption $\left(\mathrm{V}_{0+}\right)$ can be calculated from a combination of the variables of the previous equation and the rate of urinary $\left(\mathrm{V}_{\mathrm{u}}\right)$ and endogenous faecal excretion $\left(\mathrm{V}_{\mathrm{f}}\right)$.

Of the thirteen volunteers, ten were children (aged 10 months-14 years) and three were adult women (aged 22-33 years). The three adult volunteers had a significantly lower $(P<0 \cdot 001)$ $\mathrm{V}_{0+}(10 \mathrm{mg} / \mathrm{kg}$ per $\mathrm{d})$ compared with the children $(81 \mathrm{mg} / \mathrm{kg}$ per $\mathrm{d})$ and a significantly lower $(P<0.001)$ total exchangeable pool size $(76 \mathrm{mg} / \mathrm{kg})$ compared with the children $(279 \mathrm{mg} / \mathrm{kg})$.

\section{Future work}

${ }^{41} \mathrm{Ca}$ is naturally present in minute quantities in nature (approximately $10^{-15}$ of all $\mathrm{Ca}$ is ${ }^{41} \mathrm{Ca}$ ). It has a half-life of 104000 years and so is not a true stable isotope. Futhermore, it is not a radioisotope, but instead is defined as a semi-stable or cosmogenic isotope. However, it can be used as a safe tracer in human subjects because its radiation risk is extremely low. The drawback to using it is that the resulting human samples must be analysed on an accelerator MS, which are not found in many centres in the world, and the cost per sample analysis is relatively high. Subjects need to consume the ${ }^{41} \mathrm{Ca}$ label a few months before any intervention study is contemplated so as to allow the ${ }^{41} \mathrm{Ca}$ to exchange completely with trabecular and cortical bone. Several papers have been published in this area (Elmore et al. 1990; Freeman et al. 1995, 1997, 2000). The basic premise is that the rate of bone resorption can be measured from urine samples approximately $100 \mathrm{~d}$ after a ${ }^{41} \mathrm{Ca}$ dose. By this time the ${ }^{41} \mathrm{Ca}$ urine concentration will be declining very slowly with time. This indicates that all the ${ }^{41} \mathrm{Ca}$ is coming exclusively from the skeleton. A dietary intervention at this point will reveal whether the ${ }^{41} \mathrm{Ca}$ concentration changes and therefore indicates if the intervention increases or decreases bone resorption. This technique obviously has potential for pharmaceutical companies manufacturing 'anti-osteoporosis' drugs, but is particularly appropriate as a tool for investigating dietary interventions where bone biomarkers are not sensitive enough and need to be monitored for lengthy periods. Another benefit of using ${ }^{41} \mathrm{Ca}$ is that all volunteers are labelled for life. A study with a combination of a stable-isotope dose, a ${ }^{41} \mathrm{Ca}$ tracer and a controlled diet should be able to answer many of the interesting kinetic questions about $\mathrm{Ca}$.

\section{Selenium}

\section{Background}

Se has six naturally-occurring stable isotopes and exists in food as both organic and inorganic forms. The predominant dietary form is reported (Reilly, 1996) to be selenomethionine 
(SeMet), which is organic and is readily absorbed, but inorganic Se is also well absorbed. Retention of Se is higher when the element is introduced as SeMet rather than as inorganic selenite (Milner, 1990) and this difference has been found to be related to the incorporation of SeMet into non-specific cellular proteins (Sunde, 1990). Its importance in human nutrition has grown markedly since the discovery that Se is a vital component of glutathione peroxidase (Rotruck et al. 1973). Stable isotopes of Se have been used since the early 1980s (Janghorbani et al. 1981a), and much of the subsequent work has sought to ascertain if a good status indicator of biologically-active Se can be found. There are three selenocompounds in the plasma (Deagen et al. 1993), but none of them can be used as status indicators because they either contain SeMet (albumin-bound Se) or are saturable over the nutritional range of intake (glutathione peroxidase, selenoprotein $\mathrm{P}$ ). SeMet is not thought to be biologically active since much of it is stored in body proteins and its release into the metabolically-active pool will be slow.

\section{Studies}

The first use of stable isotopes of Se in conjunction with mathematical modelling was reported by Janghorbani et al. (1984). They calculated the apparent body pool size in a group of volunteers who were given a $200 \mu \mathrm{g}$ oral dose of ${ }^{74} \mathrm{Se}$ as selenite. All faeces and urine were collected for $45 \mathrm{~d}$, thereby allowing body retention of the labelled dose to be calculated during the study period. Body retention over time was found to fit a double exponential equation that yielded half-lives of approximately 2 and $162 \mathrm{~d}$ for the two body pools. The authors proposed that the first pool (half-life $2 \mathrm{~d}$ ) might relate to the Se kinetics of plasma and liver and the second pool (half-life 162 d) may be Se stored in the deeper pools such as the muscle and bone. The apparent body pool size was calculated to be approximately $10 \mathrm{mg}$, which corresponded well with autopsy data (Schroeder et al. 1970) where whole-body Se was estimated to be in the order of $14.6 \mathrm{mg}$ in a similar population group.

In a more recent paper Martin et al. (1988) renamed the apparent body size pool to be the selenite-exchangeable metabolic pool. Janghorbani et al. (1990) suggest that there are predominantly two pools of Se in the body, SeMet and selenite. The SeMet-containing pool acts as a storage site for Se whereas the selenite-exchangeable metabolic pool carries out all the physiological functions. They have proposed that the selenite-exchangeable metabolic pool be used as an indicator of Se status, since this pool is present in the whole body and not just the plasma.

The first compartmental model of Se developed using stable isotopes was that of Patterson et al. (1989). They fed $200 \mu \mathrm{g}$ enriched ${ }^{74} \mathrm{Se}$ as selenite and collected blood, urine and faeces for $12 \mathrm{~d}$ thereafter. They developed a complicated model that included four plasma pools, a liver and pancreas pool and a tissue pool (Fig. 7). Multiple plasma pools were thought necessary since more than one peak was seen in volunteers' plasma and urine data. The model has eighteen rate constants and is a priori unidentifiable. No information is given as to the uncertainty of the rate constants, so it is not possible to speculate as to whether it is a posteriori identifiable. However, some interesting findings emerge from the model. The mean residence times (the average amount of time a molecule spends in a pool or system before irreversibly leaving) in the four plasma pools are $0.02,0.18,0.74$ and $9.6 \mathrm{~d}$ respectively. The authors speculate that plasma pool 1 could either be newly-absorbed Se that has not been removed by the liver in the first-pass or a rapidly-turning-over pool in the liver. It is suggested that pool 2 may be material absorbed from the enterocyte into the lymphatic system and transported in chylomicrons or VLDL. The kinetics of pool 3 indicates that the Se found here is probably contained in glutathione peroxidase and/or selenoprotein P. The Se in pool 4 comes from the large tissue pools. The mean residence time of 


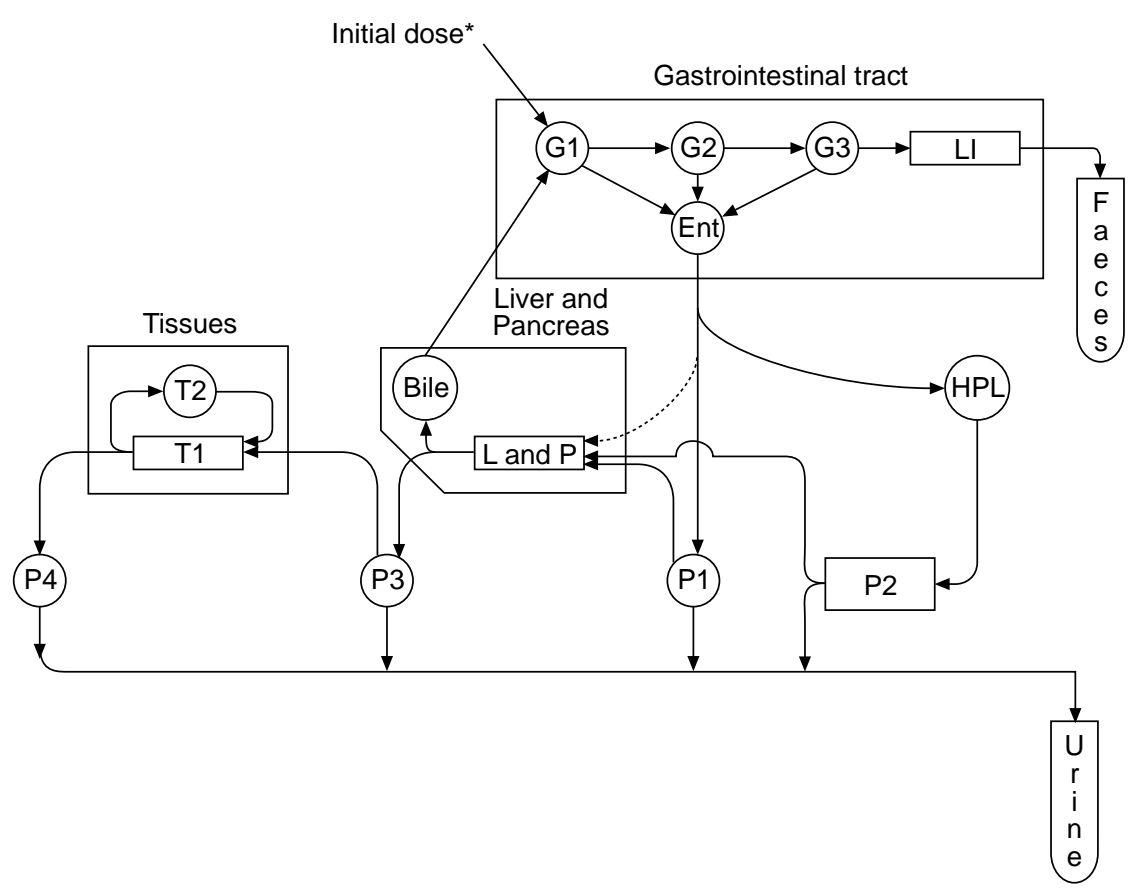

Fig. 7. Model for selenite metabolism. ${ }^{*} \rightarrow$, Site of oral tracer administration; $\rightarrow$, movement of selenium; $(\square)$, delays; G1, G2, G3, gut compartments; ENT, enterocytes; HPL a compartment in the hepatopancreatic subsystem or lymphatic system; $L$ and $P$, liver and pancreas; LI, large intestine; T1, T2, peripheral tissues, (largely skeletal muscle); P1-P4, four kinetically-distinct plasma compartments. (From Patterson et al. 1989; reproduced with permission.)

the liver-pancreas subsystem was $20 \mathrm{~d}$ and that of the tissues was $221 \mathrm{~d}$. The development of this model is examined in a paper (Patterson \& Zech, 1992) given as part of a symposium on the application of models to the determination of nutrient requirements.

A study by Ducros et al. (1997) gave an oral dose $(100 \mu \mathrm{g})$ of labelled selenite $\left({ }^{74} \mathrm{Se}\right.$, $98.2 \%$ enriched) to three groups of women. All the volunteers lived in the same area and were divided into free-living elderly (aged 64-82 years), institutionalised elderly (aged 68-82 years) and a comparison group of young women aged 31-40 years. The aim of the study was to investigate whether age and/or lifestyle influenced Se exchangeable pool size. Blood samples were taken periodically for 6 months and a two-compartment model was found to fit the resulting data. Compartment 1 had a mean pool size that ranged from $619 \mu \mathrm{g}$ for the institutionalised elderly to $835 \mu \mathrm{g}$ for the young adult. This first pool is approximately three times larger than the plasma pool (native Se plasma concentration multiplied by plasma volume) and has a halflife of approximately $1 \mathrm{~d}$. Compartment 2 had a mean pool size range of $1767 \mu \mathrm{g}$ for the institutionalised elderly and $2473 \mu \mathrm{g}$ for the young adult. The average half-life is approximately $30 \mathrm{~d}$. Compartment 1 has similar kinetics to the third plasma pool identified by Patterson et al. (1989). As blood samples were only taken from $1 \mathrm{~h}$ post-dose, no pools could be identified that turn over in less than $2 \mathrm{~h}$. The second compartment has a much shorter turnover time than the tissue compartment identified by Patterson et al. (1989). The authors suggest that this compartment may represent label, with a slow turnover, released from the peripheral tissues. They conclude that ageing has no effect on Se status. 
A SeMet model was published by Swanson et al. (1991) and was based on six adults consuming an oral dose of $200 \mu \mathrm{g}{ }^{74} \mathrm{Se}$ as L-SeMet. It was developed from the selenite model of Patterson et al. (1989) but contains some differences. A second tissue pool was connected between the third and fourth plasma pools. A pathway to the liver and pancreas system from the fourth plasma pool was also required and the first pass effect was much greater in comparison with the selenite model. The turnover times of both models are given in Table 1 .

Table 1 shows that organic Se is metabolised quite differently from inorganic Se. A major difference is that whole-body turnover is much slower with the SeMet form of Se. This difference is attributed to re-utilisation of the organic form via the pathway from the fourth plasma pool to the liver-pancreas subsystem. This pathway does not exist in selenite metabolism and, consequently, the whole-body turnover time is faster. This is in contrast to the major storage areas of the body, where we find that the turnover of SeMet is much faster than that of selenite. In a paper comparing the two models, Patterson et al. (1993) conclude that the ability to redistribute Se is beneficial if the body's requirements suddenly change. They also comment, however, that at high dietary intakes, re-utilisation of SeMet could result in excessive tissue accumulation and toxicity.

\section{Future work}

The extent to which these models may be related to the real world has been limited due to a lack of studies incorporating intrinsic labels in the test meals. Even when intrinsic labels have been used, no speciation work has been carried out to determine what proportions of the different forms of Se are present in the food. The use of Se exchangeable pool size, as a measure of status, merits further investigation through an intervention study. This would help determine whether changes in dietary intake were proportionately reflected in changes in the rapidlyexchangeable pools.

\section{Conclusions}

In conjunction with stable isotopes, mathematical modelling allows the nutritional investigator to probe the human metabolism of most minerals. Body pool sizes, kinetics and residence times can all be calculated from enriched plasma, urine and faecal samples to build up a picture of the dietary fate of a mineral. As improvements are made in MS technology, smaller doses will be required to investigate the system, which should reduce the chances that the steady-state is perturbed. If bioavailability is an issue then intrinsic labels, although more expensive, must be

Table 1. Comparison of turnover times for models of selenite (Patterson et al. 1989) and selenomethionine (Swanson et al. 1991)

(Mean values and standard deviations)

\begin{tabular}{lccccc}
\hline & \multicolumn{5}{c}{ Turnover time (d) } \\
\cline { 2 - 3 } \cline { 6 - 7 } \cline { 5 - 6 } & \multicolumn{2}{c}{ Selenite } & & \multicolumn{2}{c}{ Selenomethionine } \\
\cline { 2 - 3 } \cline { 5 - 6 } & Mean & SE & & Mean & SE \\
\hline Plasma & $2 \cdot 0$ & $0 \cdot 1$ & & $0 \cdot 6$ & $0 \cdot 1$ \\
Liver and pancreas & 20 & 5 & & $2 \cdot 4$ & $0 \cdot 3$ \\
Tissues & 221 & 33 & & 73 & 3 \\
Whole body & 147 & 13 & & 363 & 21 \\
\hline
\end{tabular}


more widely used in the future, since the form in which they enter the body will be the same as that of the native mineral. The use of the IV route of administration must be examined critically for indications that the label is not handled in the same way by the body as oral doses. Of the four minerals discussed in the present article, only studies involving Ca can really claim to have been fully validated using both oral and IV tracers. Until proven otherwise, the use of IV with other minerals must be viewed with some caution.

Although the discussion focused on $\mathrm{Ca}, \mathrm{Cu}, \mathrm{Se}$ and $\mathrm{Zn}$, the techniques described are broadly applicable to all the other minerals, provided they have at least two stable isotopes. $\mathrm{Fe}$ is the only major mineral where compartmental modelling has had no real impact. This is for two reasons. First, questions about bioavailability and requirements can be answered without modelling. Second, serum ferritin measurements are a good status indicator and therefore pool sizes are not needed. Essential nutrients such as $\beta$-carotene and folate have been labelled with stable isotopes and fed to human subjects (Burri \& Park, 1998; Clifford et al. 1998) and this area is likely to be one of increasing expansion.

More biologists should be encouraged to use modelling in their nutritional work. The Internet can be a source for encouragement and improvement, with many models already existing in cyberspace (Wastney et al. 1998).

Although stable isotopes are expensive to buy and exacting to analyse, they are the only genuinely safe way to investigate human metabolism. Compartmental modelling has been used in many scientific fields with distinction and is based on rigorous mathematical theory. The combination of the two approaches has yielded some very exciting research during the past 20 years and, it is hoped, will continue to do so for some years to come.

\section{Acknowledgements}

The author wishes to thank the BBSRC for their support of this work.

\section{References}

Abrams SA, Esteban NV, Vieira NE, Sidbury JB, Specker BL \& Yergey AL (1992) Developmental changes in calcium kinetics in children assessed using stable isotopes. Journal of Bone and Mineral Research 7, 287-293.

Abrams SA, Schanler RJ, Yergey AL, Vieira NE \& Bronner F (1994) Compartmental analysis of calcium metabolism in very-low-birth-weight infants. Pediatric Research 36, 424-428.

Abumrad N (editor) (1991) Mathematical models in experimental nutrition: Advances in amino acid and carbohydrate metabolism. Journal of Parenteral and Enteral Nutrition 15, 44S-98S.

Anderson DH (1983) Compartmental Modeling and Tracer Kinetics. Berlin: Springer-Verlag.

Atkins GL (1969) Multicompartment Models in Biological Systems. London: Methuen.

Aubert J-P, Bronner F \& Richelle LJ (1963) Quantitation of calcium metabolism theory. Journal of Clinical Investigation 42, 885-897.

Buckley WT (1988) The use of stable isotopes in studies of mineral metabolism. Proceedings of the Nutrition Society 47, 407-416.

Buckley WT (1991) A kinetic model of copper metabolism in lactating dairy cows. Canadian Journal of Animal Science 71, 155-166.

Buckley WT (1996) Application of compartmental modelling to determination of trace element requirements in humans. Journal of Nutrition 126, 2312S-2319S.

Buckley WT, Vanderpool RA, Godfrey DV \& Johnson PE (1996) Determination, stable isotope enrichment and kinetics of direct-reacting copper in blood plasma. Journal of Nutritional Biochemistry 7, 488-494.

Burri BJ \& Park J-YK (1998) Compartmental models of vitamin A and B-carotene metabolism in women. In Mathematical Modeling in Experimental Nutrition, pp. 225-237 [AJ Clifford and H-G Muller, editors]. New York: Plenum Press.

Canolty N \& Cain TP (editors) (1985) Mathematical Models in Experimental Nutrition. Athens, GA: University of Georgia. 
Carson ER, Cobelli C \& Finkelstein L (1983) The Mathematical Modeling of Metabolic and Endocrine Systems: Model Formulation, Identification, and Validation. New York: Wiley \& Sons.

Christensen MJ, Janghorbani M, Steinke FH, Istfan N \& Young VR (1983) Simultaneous determination of absorption of selenium from poultry meat and selenite in young men: application of a triple stable-isotope method. British Journal of Nutrition 50, 43-50.

Clifford AJ, Arjomand A, Dueker SR, Schneider PD, Buchholz BA \& Vogel JS (1998) The dynamics of folic acid metabolism in an adult human given a small tracer dose of ${ }^{14} \mathrm{C}$-folic acid. In Mathematical Modeling in Experimental Nutrition, pp. 239-251 [AJ Clifford and H-G Muller, editors]. New York: Plenum Press.

Clifford AJ \& Muller H-G (editors) (1998) Mathematical Modeling in Experimental Nutrition. New York: Plenum Press.

Coburn SP \& Townsend D (editors) (1996) Mathematical modeling in experimental nutrition. Advances in Food and Nutrition Research 40, 1-362.

Cousins RJ (1989) Systemic transport of zinc. In Zinc in Human Biology, pp. 79-85 [CF Mills, editor]. Berlin: Springer Verlag.

D'Addabbo A, Germinario L, Campanella G, Damato VD \& Boccuni N (1971) Contributi allo studio della degenerazione epatolenticolare (morbo di Wilson). III. Localizzazione epatica del ${ }^{64} \mathrm{Cu}$ : Studio scintigrafico e dinamico prima e dopo trattamento con B.A.L. e d-penicillamina (On hepatolenticular degeneration (Wilson's disease). III Hepatic localization of ${ }^{64} \mathrm{Cu}$ : scintigraphic and dynamic study before and after treatment with BAL and D-penicillamine). Acta Neurologica 26, 436-444.

Davis GK \& Mertz WC (1987) Copper. In Trace Elements in Human and Animal Nutrition, pp. 301-364 [W Mertz, editor]. New York: Academic Press.

Deagen JT, Butler JA, Zachara BA \& Whanger PD (1993) Determination of the distribution of selenium between glutathione peroxidase, selenoprotein P, and albumin in the plasma. Analytical Biochemistry 208, 176-181.

Department of Health (1991) Dietary reference values for food energy and nutrients for the United Kingdom. Report on Health and Social Subjects no. 41. London: H.M. Stationery Office.

Donaldson GWK, Johnson PF, Tothill P \& Richmond J (1968) Red cell survival time in man as measured by ${ }^{50} \mathrm{Cr}$ and activation analysis. British Medical Journal 2, 585-587.

Ducros V, Faure P, Ferry M, Couzy F, Biajoux I \& Favier A (1997) The sizes of the exchangeable pools of selenium in elderly women and their relation to institutionalization. British Journal of Nutrition 78, 379-396.

Dunn MA, Green MH \& Leach RM (1991) Kinetics of copper metabolism in rats: a compartmental model. American Journal of Physiology 261, E115-E125.

Elmore D, Bhattacharyya MH, Sacco-Gibson N \& Peterson DP (1990) Calcium-41 as a long-term biological tracer for bone resorption. Nuclear Instruments and Methods in Physics Research B 52, 531-535.

Fairweather-Tait SJ, Jackson ML, Fox TE, Wharf SG, Eagles J \& Croghan PC (1993) The measurement of exchangeable pools of zinc using the stable isotope ${ }^{70} \mathrm{Zn}$. British Journal of Nutrition 70, 221-234.

Foster DM, Aamodt RL, Henkin RI \& Berman M (1979) Zinc metabolism in humans: a kinetic model. American Journal of Physiology 237, R340-R349.

Foster DM, Boston RC, Jacquez JA \& Zech LA (1989) The SAAM Tutorials: An Introduction to Using Conversational SAAM (version 30). Seattle, WA: Resource Facility for Kinetic Analysis.

Fox TE, Fairweather-Tait SJ, Eagles J \& Wharf SG (1991) Intrinsic labelling of different foods with stable isotopes of zinc $\left({ }^{67} \mathrm{Zn}\right)$ for use in bioavailability studies. British Journal of Nutrition 66, 57-63.

Freeman SPHT, Beck B, Bierman JM, Caffee MW, Heaney RP, Holloway L, Marcus R, Southon JR \& Vogel JS (2000) The study of skeletal calcium metabolism with ${ }^{41} \mathrm{Ca}$ and ${ }^{45} \mathrm{Ca}$. Nuclear Instruments and Methods in Physics Research $B$ 172, 930-933.

Freeman SPHT, King JC, Vieira NE, Woodhouse LR \& Yergey AL (1997) Human calcium metabolism including bone resorption measured with ${ }^{41} \mathrm{Ca}$ tracer. Nuclear Instruments and Methods in Physics Research B 123, 266-270.

Freeman SPHT, Serfass RE, King JC, Southon JR, Fang Y, Woodhouse LR, Bench GS \& McAninch JE (1995) Biological sample preparation and ${ }^{41} \mathrm{Ca}$ AMS measurement at LLNL. Nuclear Instruments and Methods in Physics Research B 99, 557-561.

Green MH \& Green JB (1990) The application of compartmental analysis to research in nutrition. Annual Review of Nutrition 10, 41-61.

Grider A, Bailey LB \& Cousins RJ (1990) Erythrocyte metallothionein as an index of zinc status in humans. Proceedings of the National Academy of Sciences USA 87, 1259-1262.

Griffin IJ, King JC \& Abrams SA (2000) Body weight-specific zinc compartmental masses in girls significantly exceed those reported in adults: a stable isotope study using a kinetic model. Journal of Nutrition 130, 2607-2612.

Hoover-Plow J \& Chandra RK (editors) (1988) Mathematical modeling in experimental nutrition. Progress in Food and Nutrition Science 12, 211-338.

Jackson MJ, Jones DA, Edwards RHT, Swainbank IG \& Coleman ML (1984) Zinc homeostasis in man: studies using a new stable isotope-dilution technique. British Journal of Nutrition 51, 199-208.

Jacquez JA (1996) Compartmental Analysis in Biology and Medicine, (3rd ed). Ann Arbor, MA: Biomedware.

Janghorbani M, Istfan NW, Pagounes JO, Steinke FH \& Young VR (1982) Absorption of dietary zinc in man: comparison of intrinsic and extrinsic labels using a triple stable isotope method. American Journal of Clinical Nutrition 36, 537-545.

Janghorbani M, Kasper LJ \& Young VR (1984) Dynamics of selenite metabolism in young men: studies with the stable isotope tracer method. American Journal of Clinical Nutrition 40, 208-218. 
Janghorbani M, Martin RF, Kasper LJ, Sun XF \& Young VR (1990) The selenite-exchangeable pool in humans: a new concept for the assessment of selenium status. American Journal of Clinical Nutrition 51, 670-677.

Janghorbani M, Ting BTG, Young VR \& Steinke FH (1981a) Intrinsic labelling of chicken meat with stable isotopes of zinc, for intended use in human feeding studies: feasibility and design considerations. British Journal of Nutrition 46, 395-402.

Janghorbani M, Ting BTG \& Young VR (1981b) Use of stable isotopes of selenium in human metabolic studies: development of analytical methodology. American Journal of Clinical Nutrition 34, 2816-2830.

Johnson PE \& Lykken GI (1988) ${ }^{65} \mathrm{Cu}$ absorption by men fed intrinsically and extrinsically labeled whole wheat bread. Journal of Agricultural and Food Chemistry 36, 537-540.

King JC (1990) Assessment of zinc status. Journal of Nutrition 120, 1474-1479.

King JC, Raynolds WL \& Margen S (1978) Absorption of stable isotopes of iron, copper and zinc during oral contraceptive use. American Journal of Clinical Nutrition 31, 1198-1203.

Krebs NF, Miller LV, Naake VL, Lei S, Westcott JE, Fennessey PV \& Hambidge KM (1995) The use of stable isotope techniques to assess zinc metabolism. Nutritional Biochemistry 6, 292-301.

Landaw EM \& DiStefano JJ (1984) Multiexponential, multicompartmental, and noncompartmental modelling. II. Data analysis and statistical considerations. American Journal of Physiology 246, R665-R677.

Linder MC (1991) The Biochemistry of Copper. New York: Plenum Press.

Linder MC (1998) Copper transport. American Journal of Clinical Nutrition 67, 965S-971S.

Lowe NM, Green A, Rhodes JM, Lombard M, Jalan R \& Jackson ML (1993) Studies of human zinc kinetics using the stable isotope ${ }^{70} \mathrm{Zn}$. Clinical Science 84, 113-117.

Lowe NM, Shames DM, Woodhouse LR, Matel JS, Roehl R, Saccomani MP, Toffolo G, Cobelli C \& King JC (1997) A compartmental model of zinc metabolism in healthy women using oral and intravenous stable isotope tracers. American Journal of Clinical Nutrition 65, 1810-1819.

Lowman JT \& Krivit W (1963) New in vivo tracer method with the use of nonradioactive isotopes and activation analysis. Journal of Laboratory and Clinical Medicine 61, 1042-1048.

McPherson GD (1965) Stable isotopes of calcium as tracers in studies of mineral metabolism. Acta Orthopaedica Scandinavica 78, 1-86.

Marcus R, Holloway L, Wells B, Greendale G, James MK, Wasilauskas C \& Kelaghan J (1999) The relationship of biochemical markers of bone turnover to bone density changes in postmenopausal women: Results from the postmenopausal estrogen/progestin interventions (PEPI) trial. Journal of Bone Mineral Research 14, 1583-1595.

Martin RF, Janghorbani M \& Young VR (1988) Kinetics of a single administration of ${ }^{74}$ Se-selenite by oral and intravenous routes in adult humans. Journal of Parenteral and Enteral Nutrition 12, 351-355.

Mellon FA \& Sandstrom B (editors) (1996) Stable Isotopes in Human Nutrition. London: Academic Press.

Miller LV, Hambidge KM, Naake VL, Hong Z, Westcott JL \& Fennessey PV (1994) Size of zinc pools that exchange rapidly with plasma zinc in humans: alternative techniques for measuring and relation to dietary zinc intake. Journal of Nutrition 124, 268-276.

Miller LV, Krebs NF \& Hambidge KM (1998) Human zinc metabolism: advances in the modeling of stable isotope data. In Mathematical Modeling in Experimental Nutrition, pp. 253-269 [AJ Clifford and H-G Muller, editors]. New York: Plenum Press.

Milner JA (1990) Trace elements in the nutrition of children. Journal of Paediatrics 117, S147-S155.

Moser-Veillon PB (1995) Zinc needs and homeostasis during lactation. Analyst 120, 895-897.

Neer R, Berman M, Fisher L \& Rosenberg LE (1967) Multicompartmental analysis of calcium kinetics in normal adult males. Journal of Clinical Investigation 46, 1364-1379.

Owen CA (1982) Biochemical Aspects of Copper. Park Ridge, NJ: Noyes Publications.

Patterson BH, Levander OA, Helzlsouer K, McAdam PA, Lewis SA, Taylor PR, Veillon C \& Zech LA (1989) Human selenite metabolism: a kinetic model. American Journal of Physiology 257, R556-R567.

Patterson BH \& Zech LA (1992) Development of a model for selenite metabolism in humans. Journal of Nutrition 122, 709-714.

Patterson BH, Zech LA, Swanson CA \& Levander OA (1993) Kinetic modeling of selenium in humans using stable isotope tracers. Journal of Trace Elements and Electrolytes in Health and Disease 7, 117-120.

Reilly C (1996) Selenium in Food and Health. London: Chapman \& Hall.

Rotruck JT, Pope AL, Ganther HE, Hafeman DG, Swanson AB \& Hoekstra WG (1973) Selenium: biochemical role as a component of glutathione peroxidase. Science 179, 588-590.

SAAMII (1997) A program for kinetic modeling. Seattle, WA: University of Washington, Resource Faciliy for Kinetic Analysis.

Saccomani MP, Audolym S, Angio LD, Sattier R \& Cobelli C (1994) Pride: a program to test a priori global identifiability of linear compartmental models. In: Proceedings of the 10th IFAC Symposium on System Identification, pp. 25-30 [M Blanke and T Soderstrom, editors]. Copenhagen: Danish Automation Society.

Schoenheimer R \& Rittenburg D (1935) Deuterium as indicator of intermediary metabolism, I-IV. Journal of Biological Chemistry 111, 163-192.

Schroeder HA, Frost DV \& Balassa JJ (1970) Essential trace elements in man: Selenium. Journal of Chronic Diseases 23, 227-243.

Scott KC \& Turnlund JR (1994a) Compartmental model of copper metabolism in adult men. Journal of Nutritional Biochemistry 5, 342-350. 
Scott KC \& Turnlund JR (1994b) A compartmental model of zinc metabolism in adult men used to study effects of three levels of dietary copper. American Journal of Physiology 267, E165-E173.

Shipley RA \& Clark RE (1972) Tracer Methods for In Vivo Kinetics. New York: Academic Press.

Sian L, Hambidge KM, Westcott JL, Miller LV \& Fennessey PV (1993) Influence of a meal and incremental doses of zinc on changes in zinc absorption. American Journal of Clinical Nutrition 58, 533-536.

Sian L, Xiang MY, Miller LV, Tong L, Krebs NF \& Hambidge KM (1996) Zinc absorption and intestinal losses of endogenous zinc in young Chinese women with marginal zinc intakes. American Journal of Clinical Nutrition 63, 348-353.

Siva Subramanian KN \& Wastney ME (editors) (1995) Kinetic Models of Trace Element and Mineral Metabolism During Development. New York: CRC Press.

Smith SM, Wastney ME, Nyquist LE, Shih CY, Wiesmann H, Nillen JL \& Lane HW (1996) Calcium kinetics with microgram stable isotope doses and saliva sampling. Journal of Mass Spectrometry 31, 1265-1270.

Sullivan VK, Burnett FR \& Cousins RJ (1998) Metallothionein expression is increased in monocytes and erythrocytes of young men during zinc supplementation. Journal of Nutrition 128, 707-713.

Sunde RA (1990) Molecular biology of selenoproteins. Annual Review of Nutrition 10, 451-474.

Swanson CA, Patterson BH, Levander OA, Veillon C, Taylor PR, Helzlsouer K, McAdam PA \& Zech LA (1991) Human $\left[{ }^{74}\right.$ Se]selenomethionine metabolism: a kinetic model. American Journal of Clinical Nutrition 54, 917-926.

Turnlund JR (1989) The use of stable isotopes in mineral nutrition. Journal of Nutrition 119, 7-14.

Turnlund JR (1991) Bioavailability of dietary mineral to humans: the stable isotope approach. Critical Reviews in Food Science and Nutrition 30, 387-396.

Turnlund JR (1994) Future directions for establishing mineral/trace element requirements. Journal of Nutrition 124, $1765 \mathrm{~S}-1770 \mathrm{~S}$.

Turnlund JR (1998) Human whole-body copper metabolism. American Journal of Clinical Nutrition 67, 960S-964S.

Turnlund JR, Keen CL \& Smith RG (1990) Copper status and urinary and salivary copper in young men at three levels of dietary copper. American Journal of Clinical Nutrition 51, 658-664.

Turnlund JR, Keyes WR, Peiffer GL \& Scott KC (1998) Copper absorption, excretion, and retention by young men consuming low dietary copper determined by using the stable isotope ${ }^{65} \mathrm{Cu}$. American Journal of Clinical Nutrition 67, 1219-1225.

Wastney ME, Aamondt RL, Rumble WF \& Henkin RI (1986) Kinetic analysis of zinc metabolism and its regulation in normal humans. American Journal of Physiology 251, R398-R408.

Wastney ME, Gokmen IG, Aamodt RL, Rumble WF, Gordon GE \& Henkin RI (1991) Kinetic analysis of zinc metabolism in humans after simultaneous administration of ${ }^{65} \mathrm{Zn}$ and ${ }^{70} \mathrm{Zn}$. American Journal of Physiology 260 , R134-R141.

Wastney ME, House WA, Barnes RM \& Subramanian KNS (2000) Kinetics of zinc metabolism: variation with diet, genetics and disease. Journal of Nutrition 130, 1355S-1359S.

Wastney ME, Ng J, Smith D, Martin BR, Peacock M \& Weaver CM (1996) Differences in calcium kinetics between adolescent girls and young women. American Journal of Physiology 271, R208-R216.

Wastney ME, Patterson BH, Linares OA, Greif PC \& Boston RC (1999) Investigating Biological Systems Using Modeling. San Diego, CA: Academic Press.

Wastney ME, Yang DC, Andretta DF, Blumenthal J, Hylton J, Canolty N, Collins JC \& Boston RC (1998) Distributing working versions of published mathematical models for biological fields via the internet. In Mathematical Modeling in Experimental Nutrition, pp. 131-135 [AJ Clifford and H-G Muller, editors]. New York: Plenum Press.

Watson WS, Mitchell KG, Lyon TDB \& Kerr N (1999) A two-compartment model for zinc in humans. Journal of Trace Elements in Medicine and Biology 13, 141-149.

Weaver CM (1985) Intrinsic mineral labelling of edible plants: methods and uses. CRC Critical Reviews in Food Science and Nutrition 23, 75-101.

Weaver CM (1988) Isotopic tracer methodology: potential in mineral nutrition. In Trace Minerals in Foods, pp. 429-454 [KT Smith, editor]. New York: Marcel Dekker.

Wirth PL \& Linder MC (1985) Distribution of copper among multiple components of human serum. Journal of the National Cancer Institute 75, 277-284.

Wolfe RR (1992) Radioactive and Stable Isotope Tracers in Biomedicine. New York: Wiley-Liss. 


\section{Digestive Physiology of Pigs \\ Edited by J E Lindberg and B Ogle, Department of Animal Nutrition and Management, Swedish University of Agricultural Sciences, Uppsala, Sweden}

July 2001

416 pages

Hardback

ISBN 0851995179

$£ 75.00$ (US $\$ 140.00$ )

Readership: Lecturers, researchers and students in animal nutrition and animal physiology.

This book brings together edited and revised papers presented at the 8th Symposium on Digestive Physiology in Pigs held in Uppsala in June, 2000. It contains more than 100 papers from leading scientists from around the world in this subject area.

Among other features it contributes to the development of the the science relating to the effects of nutrition on gut physiology. It also creates a platform for future research, that will increase knowledge of how to optimize the nutrition of the pig and to help prevent diet-related gastrointestinal conditions.

\section{Issues Addressed:}

- Development and function of the gastrointestinal tract

- Possible interactions between nutrition and gut function

- Factors influencing gut maturation and function in prenatal and postnatal pigs

- The gastrointestinal immune system and its implications for health maintenance

- Nutrient fluxes at the intestinal level

- Nutrient utilization and metabolism by the gastrointestinal tract

- Dietary and animal related factors affecting digestion and digestive secretions

- Influence of the gut microflora on the digestive processes

- Influence of nutrition on the gut microflora

- Role of the gut microflora in the prevention of disease

\section{CABI Publishing,}

$\mathrm{CAB}$ International, Wallingford,

Oxon, OX10 8DE, UK

Tel:+44(0)1491 832111

Fax:+44(0)1491 829292

Email: orders@cabi.org

\section{CABI Publishing,}

CAB International, 10 East 40th Street, Suite 3203, New York, NY 10016, USA

Tel:+1 2124817018

Fax:+1 2126867993

Email: cabi-nao@cabi.org

For further information or to order please contact CABI Publishing, UK or an exclusive CABI Publishing distributor in your area. For pre-paid orders in the UK, please add $£ 2.75$ for the 1 st book and $60 \mathrm{p}$ for each additional book ordered (up to max. of 10). For pre-paid orders elsewhere, please add $£ 4.00$ for the 1 st book and $£ 1.00$ for each additional book. For orders not pre-paid, postage and packing will be charged according to the weight of the book. 